\title{
SOCIAL PRESENCE AND EDUCATIONAL TECHNOLOGIES IN AN ONLINE DISTANCE COURSE IN FINNISH HIGHER EDUCATION - A SOCIAL CONSTRUCTIVIST PERSPECTIVE
}

\author{
Irène Charbonneau, Stockholm University, Sweden
}

\begin{abstract}
This paper analyses the interplay of social presence and educational technology, from a social constructivist perspective, to question the current determinism prevailing in the literature. Taking an online distance course implemented in Finland as its case, the study reveals how students negotiate the way they share visual cues and personal background and experiences. Thereby, it critically examines the impetus to create more social presence through visual cues and personal information, by highlighting some of the ethical implications. Moreover, the study reveals that text-based online discussions occurring in forums provides more space for students to participate in discussions than webinars, despite being negatively perceived by students. The study also shows how students and instructors' practices have the potential to re-shape the way technologies are used in online distance education, to eventually reach more equity between students' and teachers' presences.
\end{abstract}

Keywords: Online distance course, educational technology, social constructivism, social presence

\section{Introduction}

Online distance education, defined as a mode of instruction using online technologies to operate at a distance, considerably expanded in the last decades. It led to its massification and the emergence of new actors such as traditional on-campus universities (Kaplan \& Haenlein, 2016; Griesbaum, 2017). These processes were exemplified and accelerated during the Covid19 pandemic. This brought new evidence of the need to re-think the way our social experiences of learning are transformed when moved online. In this vein, researchers analysed online social interactions and more specifically social presence, defined as the sense of being there with others in a mediated environment (Heeter, 1992). Social presence was seen as a mean to limit the feeling of isolation experienced by online students (Aragon, 2003). The strategies identified to promote social presence ranged from 
Charbonneau, l.

Social Presence and Educational Technologies in an Online Distance Course in Finnish Higher Education - A Social Constructivist Perspective

the creation of personal profiles, the incorporation of audio and visual cues, the participation in and initiation of online discussions, or the share of personal experiences (ibid.). Undoubtedly, the general incentive for social presence in online learning was influenced by broader trends towards more self-disclosure on the internet, with potential ethical issues.

A review of the literature found that research on social presence and educational technologies was characterized by a lack of theorization and by deterministic views, often due to prevailing instrumental concerns. Conceptual confusion was visible in research on social presence, which was not clearly defined in many research pieces (Lowenthal \& Snelson, 2017). Moreover, to address practical concerns, researchers examined what social presence did, in other words, its effect on learning, rather than what it was. More generally, deterministic accounts of social presence defined it as the extent to which the "illusion of direct experience was created" (Kehrwald, 2010; p.40). It then did not recognize that realities, whether online or not, were never "passively received and registered by social actors" (Mantovani \& Riva, 1999; p.4). Other research works focused on the way students projected themselves as "authentic and unique person(s)" (Lowenthal \& Snelson, 2017; p.149). Thereby, they disregarded that the way personal experiences and background information were shared varied from a context to another. On the contrary, according to the impression management theory, individuals "adjust(ed) their behavior in an ongoing dynamic relationship with other players" (Houtman, Makos, \& Meacock, 2014; p.422).

As for technologies, their lack of theorization in the literature was regularly outlined by some authors (Jones \& Czerniewicz, 2011; Issroff \& Scanlon, 2002; Bennett \& Oliver, 2011; Phillips, Kennedy, \& McNaught, 2012). For instance, many empirical research did not refer to any theory (Hew et al., 2019; Bulfin et al., 2013). This was because the literature was geared towards instrumental rather than theoretical purposes. Many research pieces aimed to improve online practices (Phillips Kennedy \& McNaught, 2012; Bennett \& Oliver, 2011). Others evaluated online distance education before closely examining what it was (Luppicin \& Lin, 2012). Moreover, many research works implicitly reproduced positivistic, essentialist and realistic perspectives (Oliver, 2013; Hamilton \& Friesen, 2013). They considered technology as an "autonomous force beyond social agency" (Batteau \& Jazayeri, 2018; p.2).

This paper presents some of the results from the author's thesis, submitted in August 2020, as part of the master's degree on international and comparative education, at Stockholm University. The thesis offered an alternative to the way social presence and educational technologies were traditionally considered in the literature, by applying a social constructivist lens. According to social constructivism, social realities did not exist outside 
Charbonneau, l.

Social Presence and Educational Technologies in an Online Distance Course in Finnish Higher Education - A Social Constructivist Perspective

individuals' continuous interpretation and were shaped by interactions with others as well as historical and cultural norms (Creswell \& Poth, 2007). It followed that individuals had the agency to shape educational technologies and social presence, but they were constrained by the environment, including its materiality because the distribution of agency varied in different learning situations. The study aimed to analyse how social presence was performed and negotiated by students and instructors through their uses of educational technologies. The study was guided by the following research question: how was social presence socially constructed through technologies across different online learning activities by instructors and students in an online distance course? To answer it, the study followed a case-study design, taking as a case an online distance course designed and implemented by the University of Oulu, Finland, and a network of Finnish universities (UniPID). The course in English was offered to international, national and exchange students enrolled in one of the network's universities. Students were encouraged to critically examine global education development and its post- / de-colonial implications. The course took place on Moodle, a learning management system and used other technologies, such as Zoom, a web-conferencing software. The course comprised of individual learning activities along with online text-based discussions in Moodle forums and webinars, on Zoom, among others. After introducing the rationale of the study, the presentation will now move to defining the methodology of the research. The results will be later presented and discussed.

\section{Methods}

This research project pursued a comparative qualitative research strategy with basic descriptive statistics, thus introducing elements of mixed-methods. It focused on the analysis of one case, informed by multiple data sources. The course was chosen because it was running for the first time, turning this research into an opportunity to reflect on its implementation. Besides, the Finnish context was interesting for being representative of current international trends in higher education. In particular, this course exemplified the ongoing efforts to internationalize the Finnish higher education system in the last decades (Haapakoski \& Stein, 2018). On the other hand, the Finnish context is characterized by a certain uniqueness: Finland now benefits from remarkable internet infrastructures (OECD, 2017; McGrath \& Åkerfeldt, 2019). It explains why most of the study participants were using electronic devices for educational purposes on a daily basis, according to survey questionnaires. Besides, in its current policies, the country partly contrasts with the ongoing marketization and corporatization in higher education, as it partly taps on the welfare state model (Ursin, 2019). In addition, the study had comparative elements: social presence was compared across different online learning activities that occurred during the 
Charbonneau, l.

Social Presence and Educational Technologies in an Online Distance Course in Finnish Higher Education - A Social Constructivist Perspective

course. The qualitative comparative method elaborated by Palmberger and Gingrich (2014) was used.

Twenty-one students agreed to participate in the research project and signed a consent form, out of the sixty-five students enrolled in the course. Multiple data sources were collected, including observations of interactions and learning activities, survey questionnaires, students' learning diaries, course material, and six semi-structured interviews with students. Observations were the main data sources and provided insights on the interactions that occurred during specific learning activities, such as the forum discussions or the webinars. Observations were completed with interviews and students' learning diaries, to shade light on students' perceptions. Survey questionnaires and course materials were also used to contextualize the study, in particular its population and its pedagogy. The data was analysed using content and interaction analysis as well as basic descriptive statistics. Quality was ensured using Tracy's (2010) eight criteria for qualitative research and the study complied with procedural ethics, in particular, the Swedish Good Research Practices (Vetenskapsrådet, 2017) and the Finnish Ethical principles of research with human participants and ethical review in the human sciences in Finland (TENK, 2019).

\section{Results}

In the study, social presence was addressed in its multiple dimensions. In particular, the results enlightened three aspects of social presence: the extent and the way (a) personal background information and experiences and (b) sensory inputs were shared and interpreted, as well as (c) one demonstrated and interpreted active presence through participation.

To begin with, in the literature, sharing personal background information and experiences was often seen as beneficial to social presence. Following this principle, in an introductory activity, students were asked to introduce themselves to the group in a discussion forum. The comparison of their introduction showed that participants emphasized their institutional belonging and their educational experiences, rather than other aspects of their identity. They were influenced by the academic norms embedded in the learning context and manifested in the activity's instructions. Also, the way participants introduced themselves was shaped by group dynamics, as noted by an interviewee: "I think, we did it in the introductory part, we discussed ourselves, we put pictures of ourselves. And to be honest, this is because somebody did it at the beginning and I am pretty sure then everybody started to copy because this is a social thing" (extract from the interviews). Those dynamics explained the homogeneity found in students' introductions. Students could read others' posts and be thus influenced by them. However, some participants' 
Charbonneau, l.

Social Presence and Educational Technologies in an Online Distance Course in Finnish Higher Education - A Social Constructivist Perspective

introductions stood out from the group because they were shaped by specific subjective and culturally situated meanings. For instance, only one participant referred to personal experiences and provided gender-related information: "I use they/them pronouns" (extract from the introductory activity). This participant also mentioned being familiar with gender studies, which explained a higher sensitivity to this issue. Consequently, the findings demonstrated that participants did not freely project their selves in the group. Social presence in this activity was a negotiation between culturally-situated and subjective meanings, interactions with others and academic norms.

Secondly, sharing visual cues was often praised for increasing social presence. In the course, along with their introductions, students could publish "a picture of themselves or of something that represents themselves" (extract from the course materials). Comparing these pictures enabled to highlight that the medium, here the photograph, did not determine participants' social presence. The majority of students shared a picture in which they were easily identifiable, such as selfies. Yet, in four cases, several individuals were represented in the photographs, making it harder to identify the participants. One picture particularly stood out because it purposively maintained anonymity: "I choose to not appear in photographs. Instead, I chose some picture cards from my material stash" (extract from the introductory activity). Interestingly, the same participant indicated "I prefer not to say" to the question about gender, in the survey questionnaire. In the picture that was published, the social presence displayed, defined here as subjectivity, did not present any unity. It was a composition of four photographs, representing various individuals and conveying different narratives. Therefore, the analysis of the photographs published in the course highlighted that, despite the current impetus to produce identifiable representations, exemplified by selfies and social network practices, students differently negotiated the degree of visual cues they want to share in the photographs.

Thirdly, the study compared students' and instructors' presence in online text-based discussions, occurring in forums, and during webinars organized through Zoom. The findings indicated that technologies were not the only determinant of the way students and instructors participated and shared of sensory inputs. In forum discussions, students' presence, understood as participation, was higher than instructors' presences, although it fluctuated. However, several interviewees negatively reflected on discussion boards and students progressively disengaged with them. Interviewees mentioned that they failed at reproducing real discussions. However, no consensus existed between interviewees on what a real discussion was. Similarly, observations revealed that students' uses of forum discussions differed: some took it as a space for discussions, others as a space to publish their individual essay. There was no group consensus on what a legitimate use was. This explained why students progressively disengaged with the activity. Another element 
Charbonneau, l.

Social Presence and Educational Technologies in an Online Distance Course in Finnish Higher Education - A Social Constructivist Perspective

explained the already mentioned disengagement and shed lights on the risks when students' and instructors' participation was unbalanced. Forums tended to shift the workload from instructors to students, as the later became the main drivers of the discussion. Despite being an efficient solution to decrease academic workload, it could create an unequal repartition, to which students could react by disengaging in the discussions.

In webinars, instructors' presences prevailed. They drove the discussion occurring through video and were the main ones to appear in the camera. On the contrary, students were reluctant in participating in the main discussion. They took over the chat functionalities as an alternative way to participate, despite instructors' efforts to engage them in the discussion through video. It was due to material constraints as Zoom gave stage on the screen to one participant at a time, that was the prevalent voice and sound. It thus emphasized the speaker. This technological feature may have intimidated students. Besides, the space left to participate in the discussion was smaller in webinars, compared to discussion forums. As a consequence, although Zoom provided more sensory inputs in theory, in practice, it did not distribute them equally but based on existing academic hierarchies that favoured instructors. To summarize, text-based online discussions provided more space for students to participate in the learning activities, while webinars favoured instructors' presence.

\section{Discussion}

The analysis of participants' introductions was in line with research on the social construction of identity and the theory of impression management. Self-representations varied from a context to another, through the influence of social interactions and norms embedded in specific contexts. However, this study showed how, in the context of low social presence, such as the introductory activity in which students interacted for the first time, students tended to produce presentations of themselves, in compliance with academic norms, to avoid standing out.

In the photographs posted for the introductory activity, students negotiated their degree of visibility and identifiability. The anonymity provided by the online environment opened up possibilities for deconstructed representations of the self. This finding was in line with research showing how anonymity in online learning environments could encourage reembodiments (Belk, 2016) or set conditions for students to filter out some information by reducing the share of visual cues (Öztok, 2013). However, the analysis of photographs also showed that they were broadly used as conveyers of visual cues. It revealed the influence of widely spread practices of image sharing on social networking sites (Zappavigna, 2016). Nowadays, space for a blurred and ambiguous identity to be displayed on the internet is 
Charbonneau, l.

Social Presence and Educational Technologies in an Online Distance Course in Finnish Higher Education - A Social Constructivist Perspective

increasingly reduced (Floridi, 2012, as cited in Belk, 2013; p.487). Individuals are more and more encouraged to share visual cues and information to identify them. Throughout the introductory activity, it was exemplified in the way most photographs represented participants as the focus of the photographs, in clearly identifiable ways, often in the form of portrays or selfies. Attempts to augment visual cues raised ethical issues as it emphasized visual cues as the main determinant for social presence, with risks of conveying prejudices.

The findings questioned the belief that video-conferencing tools created more direct experience, compared to forums by showing that in both cases, social presence was negotiated. Online forums gave more space for students' presence, while webinars favoured instructors' presence. This fact is illuminating by those technologies' genesis. Online forums were originally compared to a virtual agora as they opened up a space of democratization (Street \& Wright, 2007; Papacharissi, 2002). On the contrary, Zoom was first produced for business meetings. The way it distributed participants' presences was more unequal. Yet, the study showed that students negatively appraised forum discussions. Students' ways of participating in webinars tended to reproduce academic hierarchies. This corroborated with students' tendencies to endorse conventional learning habitus (Costa et al., 2018). Even if technologies and pedagogies can open avenues for emancipatory learning practices, they are not the main determinant of students' practices. The latter are strongly influenced by academic traditions that provide a stable framework in which students are familiar to navigate. For alternatives uses to emerged, instructors and students need to learn how tools can be utilized and agree on the way they should be used. In addition, alternative uses also occurs within the limits of material and structural constraints. The two technologies compared in this study, Zoom and Moodle, differ in terms of flexibility. Moodle, for instance is open source and more adaptable. However, configuring it requires time and expertise, two elements that can contradict the imperative of efficiency and the industrialization of educational technologies, that are at the core of current trends in online distance education. Finally, encouraging students' to demonstrate active social presence should be critically reflected upon. It could overburden students, and could even become a tool for surveillance and control. Signalling one's presence could be used by instructors to track participation (ibid.). This could be made even more problematic if it occurs along with a dis-balanced participation between students and instructors.

\section{Conclusion}

To conclude, this study helped to understand how using technologies and inhabiting the online space could reshape social relations and learning processes. In this case, students' and instructors' social presences were reconfigured when moved online. However, the 
Charbonneau, l.

Social Presence and Educational Technologies in an Online Distance Course in Finnish Higher Education - A Social Constructivist Perspective

analysis also revealed how academic norms and hierarchies were sustained, even by students themselves, especially when no consensus existed on the way technologies should be used. Developing and agreeing on what kinds of shared digital competences is required could be a way of building this consensus. In addition, this study highlighted some of the ethical implications when encouraging students to increase their social presence: from risks associated with online self-disclosures to the ones linked to inequitable and unbalanced presences between instructors and students.

\section{References}

Aragon, S. R. (2003). Creating social presence in online environments. New Directions for Adult and Continuing Education, 2003(100), 57-68. https://doi.org/10.1002/ace.119

Batteau, A. W., \& Jazayeri, M. (2018). Technology. In H. Callan (Ed.), The International Encyclopedia of Anthropology (pp. 1-11). Hoboken, New Jersey: John Wiley \& Sons. https://doi.org/10.1002/9781118924396.wbiea1678

Belk, R. W. (2013). Extended Self in a Digital World. Journal of Consumer Research, 40(3), 477- 500. https://doi.org/10.1086/671052

Belk, R. W. (2016). Extended self and the digital world. Current Opinion in Psychology, 10, 50-54. https://doi.org/10.1016/j.copsyc.2015.11.003

Bennett, S., \& Oliver, M. (2011). Talking back to theory: The missed opportunities in learning technology research. Research in Learning Technology, 19(3), 179-189. https://doi.org/10.3402/rlt.v19i3.17108

Bulfin, S., Henderson, M., \& Johnson, N. (2013). Examining the use of theory within educational technology and media research. Learning, Media and Technology, 38(3), 337-344. https://doi.org/10.1080/17439884.2013.790315

Costa, C., Murphy, M., Pereira, A. L., \& Taylor, Y. (2018). Higher education students' experiences of digital learning and (dis) empowerment. Australasian Journal of Educational Technology, 34(3), 140-152. https://doi.org/10.14742/ajet.3979

Creswell, J. W., \& Poth, C. N. (2007). Qualitative inquiry and research method: Choosing among five approaches ( $2^{\text {nd }}$ ed.). Newbury Park: SAGE Publications.

Griesbaum, J. (2017). Trends in e-learning: Impacts of social mobile technologies on information behavior, formal learning and the educational market. International Journal of Information and Education Technology, 7(2), 123. Retrieved from http://www.ijiet.org/show-84-967-1.html 
Charbonneau, l.

Social Presence and Educational Technologies in an Online Distance Course in Finnish Higher Education - A Social Constructivist Perspective

Haapakoski, J., \& Stein, S. (2018). The ethical implications of internationalisation for a knowledge economy: A critical discourse analysis approach to contemporary strategies in Finland and Canada. In V. Korhonen \& A. Pauliina (Eds.), Internationalisation and Transnationalisation in Higher Education (pp.41-67). Bern: Peter Lang. https://doi.org/10.3726/b11212

Hamilton, E., \& Friesen, N. (2013). Online Education: A Science and Technology Studies perspective/Éducation en ligne: Perspective des études en science et technologie. Canadian Journal of Learning and Technology/La revue canadienne de l'apprentissage et de la technologie, 39(2), 1-21. https://doi.org/10.21432/T2001C

Heeter, C. (1992). Being there: The subjective experience of presence. Presence: Teleoperators \& Virtual Environments, 1(2), 262-271. https://doi.org/10.1162/pres.1992.1.2.262

Hew, K. F., Lan, M., Tang, Y., Jia, C., \& Lo, C. K. (2019). Where is the "theory" within the field of educational technology research? British Journal of Educational Technology, 50(3), 956-971. https://doi.org/10.1111/bjet.12770

Houtman, E., Makos, A., \& Meacock, H. L. (2014). The intersection of social presence and impression management in online learning environments. E-Learning and Digital Media, 11(4), 419-430. https://doi.org/10.2304/elea.2014.11.4.419

Issroff, K., \& Scanlon, E. (2002). Educational technology: The influence of theory. Journal of Interactive Media in Education, 2002(6), 1-13. http://doi.org/10.5334/2002-6

Jones, C. R., \& Czerniewicz, L. (2011). Editorial: Theory in learning technology. Research in Learning Technology, 19(3), 173-177. https://doi.org/10.1080/21567069.2011.632491

Kaplan, A. M., \& Haenlein, M. (2016). Higher education and the digital revolution: About MOOCs, SPOCs, social media, and the Cookie Monster. Business Horizons, 59(4), 441450. https://doi.org/10.1016/j.bushor.2016.03.008

Kehrwald, B. (2010). Being online: Social presence as subjectivity in online learning. London Review of Education, 8(1), 39-50. https://doi.org/10.1080/14748460903557688

Lowenthal, P. R., \& Snelson, C. (2017). In search of a better understanding of social presence: an investigation into how researchers define social presence. Distance Education, 38(2), 141-159. https://doi.org/10.1080/01587919.2017.1324727

Luppicini, R., \& Lin, X. (2012). Student 2.0 revisited: The paradox of anonymity and identity in the digital world. In R. Luppicini \& A. K. Haghi (Eds.), Education for a Digital World ( $1^{\text {st }}$ ed. pp. 205-216). New Jersey: Apple Academic Press. https://doi.org/10.1201/b13108 
Charbonneau,l.

Social Presence and Educational Technologies in an Online Distance Course in Finnish Higher Education - A Social Constructivist Perspective

Mantovani, G., \& Riva, G. (1999). "Real” presence: how different ontologies generate different criteria for presence, telepresence, and virtual presence. Presence, 8(5), 540550. https://doi.org/10.1162/105474699566459

McGrath, C., \& Åkerfeldt, A. (2019). Educational technology (EdTech): Unbounded opportunities or just another brick in the wall? In A. Larsson \& R. Teigland (Eds.), Digital Transformation and Public Services ( $1^{\text {st }}$ ed. pp. 143-157). Abigdon: Routledge. https://doi.org/10.4324/9780429319297

OECD. (2017). OECD Reviews of Innovation Policy: Finland 2017. Paris: OECD Publishing. https://doi.org/10.1787/9789264276369-en

Oliver, M. (2011). Technological determinism in educational technology research: some alternative ways of thinking about the relationship between learning and technology. Journal of Computer Assisted Learning, 27(5), 373-384. https://doi.org/10.1111/j.13652729.2011.00406.x

Oliver, M. (2013). Learning technology: Theorising the tools we study. British Journal of Educational Technology, 44(1), 31-43. https://doi.org/10.1111/j.14678535.2011.01283.x

Öztok, M. (2013). The hidden curriculum of online learning: discourses of whiteness, social absence, and inequity. [Doctoral dissertation, University of Toronto]. TSpace.

Retrieved from

https://tspace.library.utoronto.ca/bitstream/1807/43687/1/Oztok_Murat_201311_Ph D_thesis.pdf

Palmberger, M. \& Gingrich, A. (2014). Qualitative Comparative Practices: Dimensions, Cases and Strategies. In Flick, U. (Ed.), The SAGE handbook of qualitative data analysis (pp.94-108). Newbury Park: SAGE Publications. https://dx.doi.org/10.4135/9781446282243.n7

Papacharissi, Z. (2002). The virtual sphere: The internet as a public sphere. New Media \& Society, 4(1), 9-27. https://doi.org/10.1177/14614440222226244

Phillips, R., Kennedy, G., \& McNaught, C. (2012). The role of theory in learning technology evaluation research. Australasian Journal of Educational Technology, 28(7), 1103-1118. https://doi.org/10.14742/ajet.791

Street, J., \& Wright, S. (2007). Democracy, deliberation and design: the case of online discussion forums. New Media and Society, 9(5), 849-869. https://doi.org/10.1177/1461444807081230 
Charbonneau, l.

Social Presence and Educational Technologies in an Online Distance Course in Finnish Higher

Education - A Social Constructivist Perspective

TENK. (2019). The ethical principles of research with human participants and ethical review in the human sciences in Finland. Helsinki: Finnish National Board on Research Integrity.

https://www.tenk.fi/sites/tenk.fi/files/Ihmistieteiden_eettisen_ennakkoarvioinnin_o hje_2019.pdf

Tracy, S. J. (2010). Qualitative quality: Eight "big-tent” criteria for excellent qualitative research. Qualitative Inquiry, 16(10), 837-851.

https://doi.org/10.1177/1077800410383121

Ursin, J. (2019). Higher Education Reforms in Finland: From a Ponderous to a More Agile System? In B. Broucker, K. De Wit, J. C. Verhoeven, \& L. Leišytė (Eds.), Higher Education System Reform: An International Comparison after Twenty Years of Bologna (pp. 67-77). Rotterdam: Brill Sense.

Vetenskapsrådet. (2017). Good Research Practice. Stockholm: Swedish Research Council. Retrieved from https://www.vr.se/download/18.5639980c162791bbfe697882/1555334908942/GoodResearchPractice_VR_2017.pdf

Zappavigna, M. (2016). Social media photography: construing subjectivity in Instagram images. Visual Communication, 15(3), 271-292. https://doi.org/10.1177/1470357216643220 